\title{
An Ion Channel Essential for Sensing Chemical Damage
}

\author{
Lindsey J. Macpherson, ${ }^{1 \star}$ Bailong Xiao, ${ }^{1 \star}$ Kelvin Y. Kwan, ${ }^{2 \star}$ Matt J. Petrus, ${ }^{3}$ Adrienne E. Dubin, ${ }^{1}$ SunWook Hwang, ${ }^{4}$ \\ Benjamin Cravatt, ${ }^{1}$ David P. Corey, ${ }^{2}$ and Ardem Patapoutian ${ }^{1,3}$ \\ ${ }^{1}$ Department of Cell Biology, The Scripps Research Institute, La Jolla, California 92037, 2Department of Neurobiology, Howard Hughes Medical Institute, \\ Harvard Medical School, Boston, Massachusetts 02115, ${ }^{3}$ Genomics Institute of the Novartis Research Foundation, San Diego, California 92121, and ${ }^{4}$ College \\ of Medicine, Korea University, Seoul 136-705, South Korea
}

Tissue damage and its downstream consequences are experimentally assayed by formaldehyde application, which indiscriminately modifies proteins and is presumed to cause pain through broadly acting mechanisms. Here we show that formaldehyde activates the ion channel TRPA1 and that TRPA1-deficient mice exhibit dramatically reduced formaldehyde-induced pain responses. 4-Hydroxynonenal, a reactive chemical produced endogenously during oxidative stress, and other related aldehydes also activate TRPA1 in vitro. Furthermore, painful responses to iodoacetamide, a nonspecific cysteine-alkylating compound, are abolished in TRPA1-deficient mice. Therefore, although these reactive chemicals modify many proteins, the associated pain appears mainly dependent on a single ion channel.

Key words: formaldehyde; TRPA1; TRP; thermoTRP; 4-HNE; pain; somatosensory

\section{Introduction}

Pain information begins at free nerve endings of specialized sensory neurons called nociceptors (Julius and Basbaum, 2001). Tissue injury causes these nerve terminals to depolarize, sending a danger signal to the brain. TRPA1, a member of the transient receptor potential (TRP) family of ion channels expressed in nociceptive neurons, is activated by reactive chemicals such as cinnamaldehyde, mustard oil, and iodoacetamide (IA) that form covalent adducts with free cysteines and lysines in numerous proteins (Story et al., 2003; Bandell et al., 2004; Jordt et al., 2004; Bautista et al., 2005; Macpherson et al., 2005; Hinman et al., 2006; Dhaka et al., 2007; Macpherson et al., 2007). The small saturated aldehyde formaldehyde reacts with a variety of amino acids by nucleophilic addition, can irreversibly crosslink proteins, and is used in standard assays for pain and inflammation attributable to tissue damage (Tjolsen et al., 1992; Metz et al., 2004). 4-Hydroxynonenal (4$\mathrm{HNE}$ ) is an $\alpha, \beta$-unsaturated hydroxyalkenal that is produced by lipid peroxidation in cells during oxidative stress. It can bind to cysteine, histidine, and lysine residues in proteins via a Michael addition reaction (Uchida, 2003). Because of this reactivity, we hypothesized that formaldehyde, 4-HNE, and other aldehydes might activate TRPA1.

Received Aug. 8, 2007; revised Sept. 4, 2007; accepted Sept. 5, 2007.

This work was supported by National Institutes of Health Grants DE016927 and R01NS046303 and by the Novartis Research Foundation. L.J.M. is the recipient of a Ruth Kirschstein Predoctoral Fellowship. B.X. is the recipient of a Canadian Institutes of Health Research Fellowship Award and an Alberta Heritage Foundation for Medical Research Fellowship Award. We thank T. Earley, M. Garrett, and J. Mathur for technical help and K. Baldwin, M. Bandell, A. Dhaka, N. Hong, U. Muller, P. Schultz, and L. Stowers for valuable input.

*L.J.M., B.X., and K.Y.K. contributed equally to this work.

Correspondence should be addressed to Dr. Ardem Patapoutian, Department of Cell Biology, The Scripps Research Institute, 10550 North Torrey Pines Road, ICND 210F, La Jolla, CA 92037. E-mail: apatapou@gnf.org.

DOI:10.1523/JNEUROSCI.3600-07.2007

Copyright $\odot 2007$ Society for Neuroscience $\quad$ 0270-6474/07/2711412-04\$15.00/0

\section{Materials and Methods}

4-HNE was purchased from EMD Biosciences (San Diego, CA). All other chemicals were purchased from Sigma-Aldrich (St. Louis, MO). Ratiometric calcium imaging, Fluorometric Imaging Plate Reader (FLIPR), and electrophysiology were performed essentially as described previously (Macpherson et al., 2007). Inside-out patches were derived from HEK293T cells transiently transfected with mTRPA1-IRES-YFP and maintained in growth medium with or without $10 \mu \mathrm{M}$ ruthenium red at $37^{\circ} \mathrm{C}$ for $1 \mathrm{~d}$, followed by $33^{\circ} \mathrm{C}$ for $1-2 \mathrm{~d}$. Cells were continuously perfused at $27-28^{\circ} \mathrm{C}$ with $0 \mathrm{Ca}$ buffer containing (in mM) $124.5 \mathrm{NaCl}, 2$ $\mathrm{MgCl}_{2}, 10$ HEPES, and 5 EGTA, $\mathrm{pH} 7.4$, in the absence or presence of 1 mM formaldehyde [ $37 \%$ stock diluted directly into buffer $(0.008 \%)$ ]. Fire-polished recording electrodes had resistances of 3-5 $\mathrm{M} \Omega$ when containing $0 \mathrm{Ca}$ buffer. All behavioral analyses were conducted on littermate mice $6-16$ weeks old, at room temperature $\left(22-24^{\circ} \mathrm{C}\right)$. Animals were acclimated for at least $20 \mathrm{~min}$ to their testing environment before all experiments (Dhaka et al., 2007). Student's $t$ test was used for all statistical calculations.

\section{Results and Discussion}

Formaldehyde activated heterologously expressed TRPA1 assayed by ratiometric $\mathrm{Ca}^{2+}$ imaging and FLIPR (Fig. $1 \mathrm{~A}$ and data not shown). The $\mathrm{EC}_{50}$ value $(357 \mu \mathrm{M})$ was determined by fitting the curve to a nonlinear regression sigmoidal concentration response model. Longer-chain aldehydes (C3-C12, expected to be less reactive because of steric hindrance and/or electron-donating effects of the extended R group) do not activate TRPA1, whereas acetaldehyde activates TRPA1 to a lesser extent than formaldehyde (Fig. 1, left; and data not shown).

Although numerous natural compounds have been found to activate TRPA1, an endogenous chemical activator of TRPA1 remains unidentified. Similar to TRPA1 agonists cinnamaldehyde and acrolein, 4 -HNE is an $\alpha, \beta$-unsaturated aldehyde and is produced by lipid peroxidation in cells during oxidative stress. Considered to be the compound primarily responsible for the pathological effects of oxidative stress, 4 -HNE can bind to cysteine, histidine, and lysine residues in proteins via Michael addi- 
A

Aldehydes<smiles>[R]C=O</smiles>

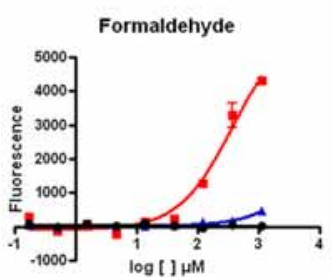

Acetaldehyde

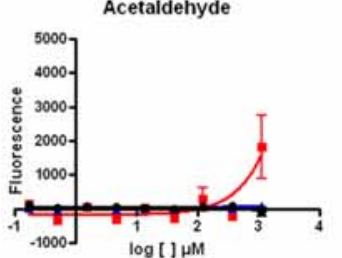

Propanal

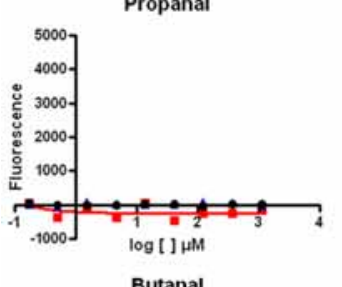

Butanal

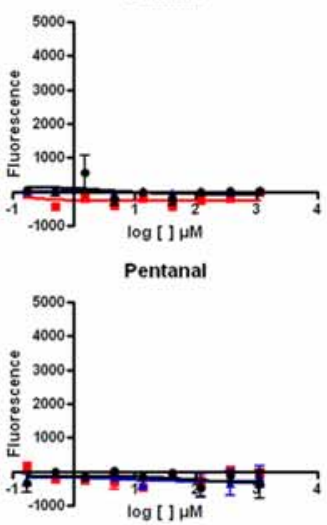

C

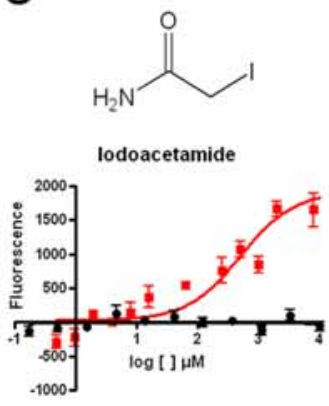

B

\section{$\alpha, \beta$ unsaturated aldehydes}
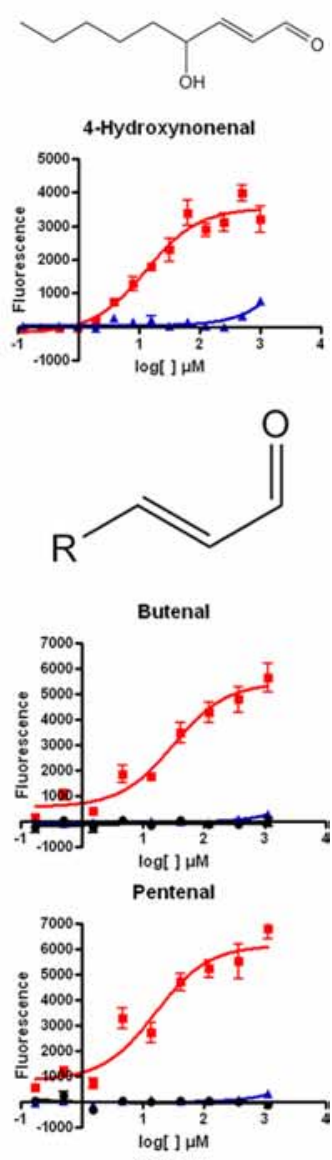

Hexenal
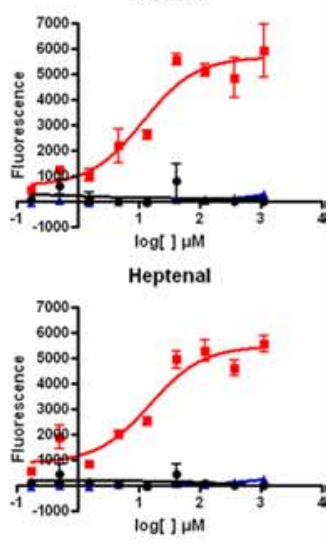

Octenal

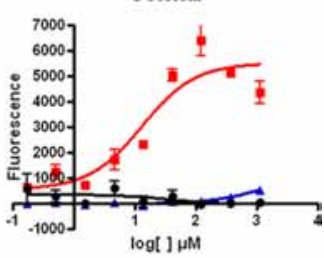

tion reaction (Uchida, 2003). We find 4-HNE to be a potent activator of TRPA1, with an $\mathrm{EC}_{50}$ of $13 \mu \mathrm{M}$ (Fig. $1 \mathrm{~B}$ and data not shown). This is physiologically relevant, because oxidative stress is thought to cause accumulation of HNE at $10 \mu \mathrm{M}$ to $5 \mathrm{~mm}$ in membranes (Uchida, 2003). Other highly reactive $\alpha, \beta$ unsaturated aldehyde compounds were also tested to see whether all such chemicals activate TRPA1. C4-C $8 \alpha, \beta$-unsaturated aldehydes activated heterologously expressed TRPA1 with $\mathrm{EC}_{50}$ values between 10 and $20 \mu \mathrm{M}$ (Fig. 1 B). Longer carbon chains (C9C11) were unable to activate TRPA1 or produced high background $\mathrm{Ca}^{2+}$ levels in Chinese hamster ovary $(\mathrm{CHO})$ cells (data not shown). Furthermore, none of the compounds tested activated TRPV1, the capsaicin-, heat-, and $\mathrm{pH}$-activated ion channel coexpressed with TRPA1 in the dorsal root ganglion (DRG) (Fig. 1) (Story et al., 2003).

We then assayed the effect of formaldehyde on TRPA1 electrophysiologically. A pulse of $1 \mathrm{~mm}$ formaldehyde to inside-out patches expressing TRPA1 revealed continued activity for $>25$ min that was reversibly reduced by menthol, a TRPA1 blocker (Fig. 2) (Macpherson et al., 2006). This suggests that formaldehyde activates TRPA1 through covalent modification, similar to the activation mechanism of mustard oil and cinnamaldehyde.

We also investigated the effect of formaldehyde on TRPA1 in native cells. We found that formaldehyde activates the population of DRG neurons that responds to the TRPA1 activator mustard oil (Fig. 3A). DRG neurons cultured from TRPA1-deficient mice (Bautista et al., 2006; Kwan et al., 2006) were insensitive to formaldehyde but retained capsaicin-evoked TRPV1 activity (Fig. 3B). Therefore, TRPA1 is solely responsible for the $\mathrm{Ca}^{2+}$ influx observed in DRG neurons induced by this nonselective reactive compound.

We next asked whether TRPA1 is involved in mediating nociception elicited by formaldehyde (formalin) injection. It is generally assumed that the pain caused by formaldehyde is attributable to nonspecific mechanisms of tissue damage (Tjolsen et al., 1992; Metz et al., 2004). We tested the response of wild-type and TRPA1-deficient littermates to $0.2 \%$ (66 mM) formaldehyde intraplantar injection in the hindpaw through analysis of nociceptive behavior during acute $(0-10$ min postinjection) and inflammatory (10-30 min) phases (Tjolsen et al., 1992). Remarkably, TRPA1-deficient mice displayed strongly impaired nociceptive responses to formaldehyde injections (Fig. 3C).

The role of TRPA1 in sensing pain is not specific to formaldehyde-induced chemical damage. IA, a general cysteinereactive reagent, specifically activated TRPA1 (Figs. 1C, 4A,B) (Macpherson et al., 2007). Although IA has not previously been tested in pain behavioral assays, we found that $15 \mathrm{~mm}$ IA injections in the hindpaw induced acute nociceptive responses in wild-type mice. Dramatically, these behaviors were absent in TRPA1-deficient mice (Fig. 4C). Our data suggest that TRPA1 is a chemical nocisensor with broad specificity in vivo. It is surprising that a single ion channel plays such an essential role in propagating the pain response to chemicals that mediate widespread protein modification and tissue damage.

Note. Trevisani et al. (2007) and McNamara et al. (2007) very recently reported the action of $4-\mathrm{HNE}$ and formaldehyde on TRPA1, respectively.

\section{References}

Bandell M, Story GM, Hwang SW, Viswanath V, Eid SR, Petrus MJ, Earley TJ, Patapoutian A (2004) Noxious cold ion channel TRPA1 is activated by pungent compounds and bradykinin. Neuron 41:849-857.
Figure 1. Formaldehyde and 4-HNE activate heterologously expressed TRPA1.
Concentration-dependence curves of aldehydes $C 1-C 5(A), 4-H N E$ and $\alpha, \beta$-unsaturated aldehydes $(4-C 8(B)$, and IA ( $C$ ) on heterologously expressed TRPA1, TRPV1, and naive CHO cells determined by FLIPR are shown. 
Bautista DM, Movahed P, Hinman A, Axelsson HE, Sterner O, Hogestatt ED, Julius D, Jordt SE, Zygmunt PM (2005) Pungent products from garlic activate the sensory ion channel TRPA1. Proc Natl Acad Sci USA 102:12248-12252.

Bautista DM, Jordt SE, Nikai T, Tsuruda PR, Read AJ, Poblete J, Yamoah EN, Basbaum AI, Julius D (2006) TRPAl mediates the inflammatory actions of environmental irritants and proalgesic agents. Cell 124:1269-1282.

Dhaka A, Murray AN, Mathur J, Earley TJ, Petrus MJ, Patapoutian A (2007) TRPM8 is required for cold sensation in mice. Neuron 54:371-378.

Hinman A, Chuang HH, Bautista DM, Julius D (2006) TRP channel activation by reversible covalent modification. Proc Natl Acad Sci USA 103:19564-19568.

Jordt SE, Bautista DM, Chuang HH, McKemy DD, Zygmunt PM, Hogestatt ED, Meng ID, Julius D (2004) Mustard oils and cannabinoids excite sensory nerve fibres through the TRP channel ANKTM1. Nature 427:260-265.

Julius D, Basbaum AI (2001) Molecular mechanisms of nociception. Nature 413:203-210.

Kwan KY, Allchorne AJ, Vollrath MA, Christensen A, Zhang DS, Woolf CJ, Corey DP (2006) TRPA1 contributes to cold, mechanical, and chemical nociception but is not essential for hair-cell transduction. Neuron 50:277-289.

Macpherson LJ, Geierstanger BH, Viswanath V, Bandell M, Eid SR, Hwang S, Patapoutian A (2005) The pungency of garlic: activation of TRPA1 and TRPV1 in response to allicin. Curr Biol 15:929-934.

Macpherson LJ, Hwang SW, Miyamoto T, Dubin AE, Patapoutian A, Story GM (2006) More than cool: Promiscuous relationships of menthol and other sensory compounds. Mol Cell Neurosci 32:335-343.

Macpherson LJ, Dubin AE, Evans MJ, Marr F, Schultz PG, Cravatt BF, Patapoutian A (2007) Noxious compounds activate TRPA1 ion channels through covalent modification of cysteines. Nature 445:541-545.

McNamara CR, Mandel-Brehm J, Bautista DM, Siemens J, Deranian KL, Zhao M, Hayward NJ, Chong JA, Julius D, Moran MM, Fanger CM (2007) TRPA1 mediates formalin-induced pain. Proc Natl Acad Sci USA 104:13525-13530.

Metz B, Kersten GF, Hoogerhout P, Brugghe HF, Timmermans HA, de Jong A, Meiring H, ten Hove J, Hennink WE, Crommelin DJ, Jiskoot W (2004) Identification of formaldehyde-induced modifications in proteins: reactions with model peptides. J Biol Chem 279:6235-6243.

Story GM, Peier AM, Reeve AJ, Eid SR, Mosbacher J, Hricik TR, Earley TJ, Hergarden AC, Andersson DA, Hwang SW, McIntyre P, Jegla T, Bevan S, Patapoutian A (2003) ANKTM1, a TRP-like channel expressed in nociceptive neurons, is activated by cold temperatures. Cell 112:819-829.

Tjolsen A, Berge OG, Hunskaar S, Rosland JH, Hole K (1992) The formalin test: an evaluation of the method. Pain 51:5-17.

Trevisani M, Siemens J, Materazzi S, Bautista DM, Nassini R, Campi B, Ima-
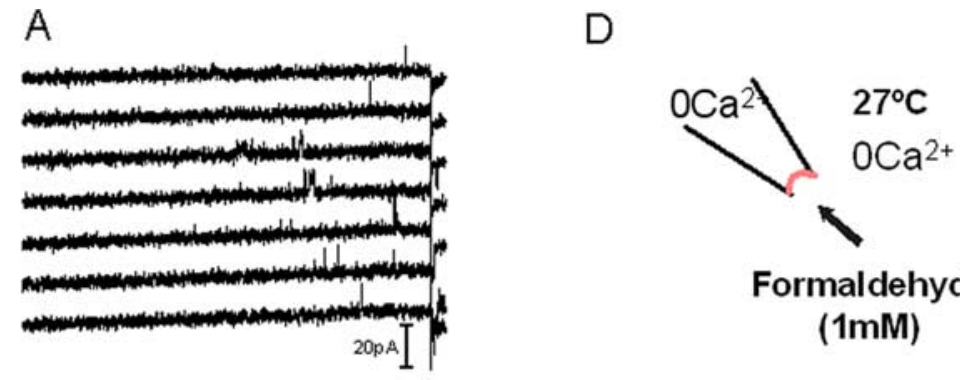

Formaldehyde (1mM)

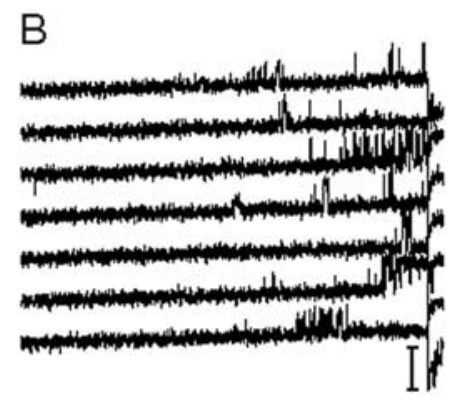

E
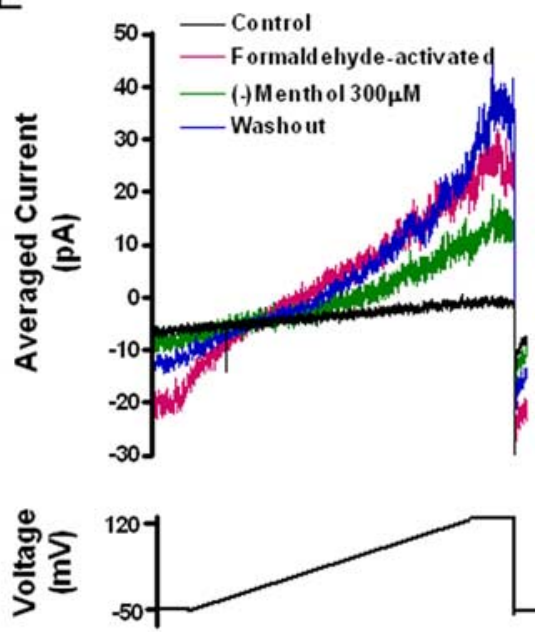

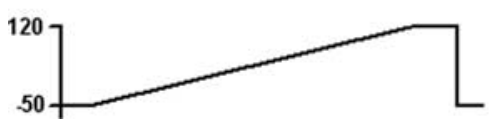

Figure 2. Formaldehyde irreversibly activates TRPA1. $\boldsymbol{A}$, In control conditions, transient single-channel activity is observed at depolarized potentials in an inside-out patch derived from an HEK293T cell transiently expressing mTRPA1 (transient openings are observed in 18 of 40 sweeps before addition of formaldehyde). $\boldsymbol{B}$, Bath application of $1 \mathrm{~mm}$ formaldehyde increases channel activity with a latency of $\sim 1 \mathrm{~min}$ (representative traces are shown). $\boldsymbol{C}$, Channel activity is still observed after washout of formaldehyde [shown are representative traces (i.e., every third sweep) acquired 2-3 min after initiation of washout]. In $\boldsymbol{A}-\boldsymbol{C}$, membrane voltage was held at $-50 \mathrm{mV}$ and ramped to $+120 \mathrm{mV}$ over $840 \mathrm{~ms}$ and maintained at $+120 \mathrm{mV}$ for 85 ms before returning to the holding potential (below $\boldsymbol{C}$ ). Voltage ramps were applied every $5 \mathrm{~s}$. The duration of each sweep is $1 \mathrm{~s}$. $\boldsymbol{D}$, Diagram of the experimental protocol. The solution used in the bath and pipette was deplete of calcium. The chamber was continuously perfused at $27^{\circ} \mathrm{C} . \boldsymbol{E}$, Averaged current traces (every third sweep) are shown for the first $200 \mathrm{~s}$ in the control solution (black; $n=13$ sweeps), after formaldehyde-induced current activity stabilized during washout (magenta; $n=9$ sweeps), during application of $300 \mu \mathrm{m}$ $(-)$ menthol (green; $n=7$ sweeps), and during washout of $(-$ )menthol (blue; $n=13$ sweeps). TRPA1 activity continued for 25 min before membrane integrity was lost. In five other experiments, similar results were obtained. TRPA1 activity was maintained for $23 \pm 9 \min (n=6)$ after washout of formaldehyde (note that this is an underestimate because of loss of membrane integrity).

machi N, Andre E, Patacchini R, Cottrell GS, Gatti R, Basbaum AI, Bunnett NW, Julius D, Geppetti P (2007) 4-Hydroxynonenal, an endogenous aldehyde, causes pain and neurogenic inflammation through activation of the irritant receptor TRPA1. Proc Natl Acad Sci USA 104:13519-13524.

Uchida K (2003) 4-Hydroxy-2-nonenal: a product and mediator of oxidative stress. Prog Lipid Res 42:318-343. 


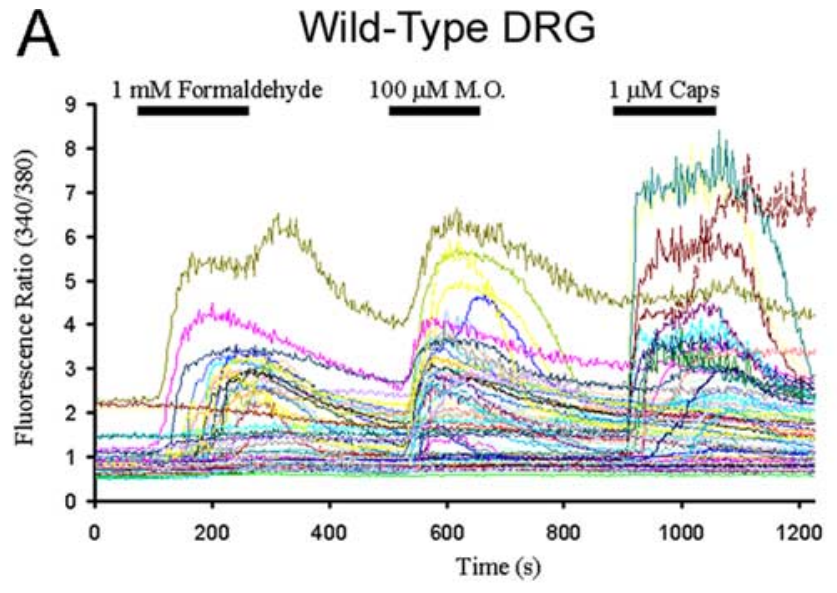

B

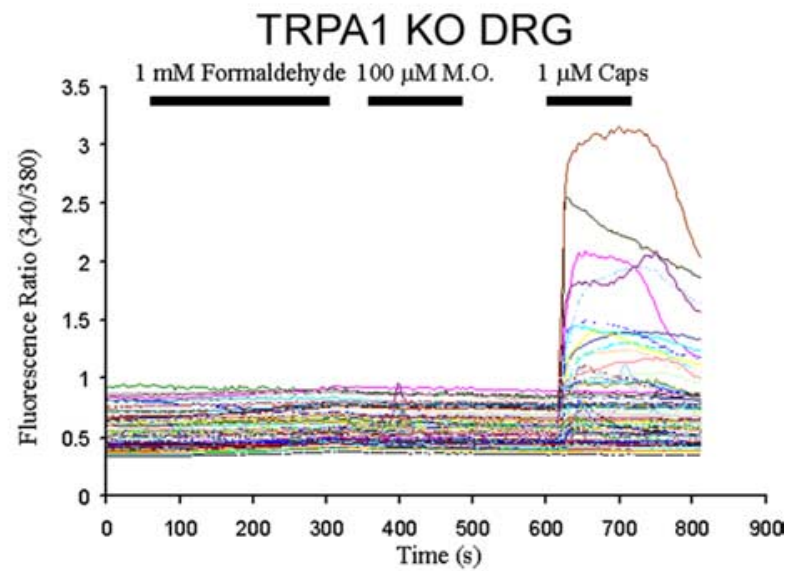

C

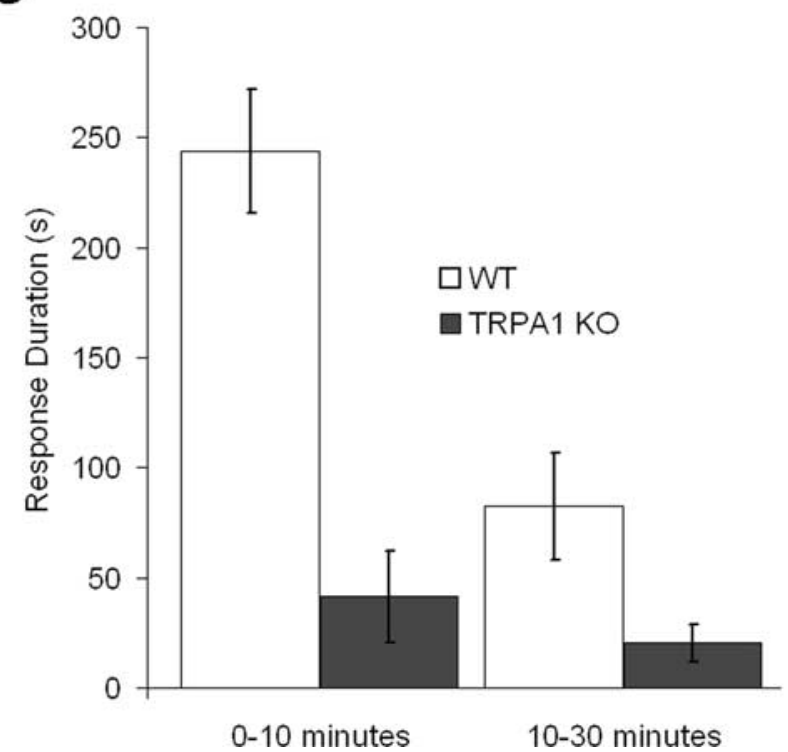

Figure 3. Formaldehyde elicits pain through TRPA1. $A, B$, Formalin exclusively activates TRPA1 in DRG neurons. Ratiometric calcium imaging of cultured adult DRG neurons from wildtype and TRPA1-deficient mice is shown. Seventy-one percent of mustard oil (M.0.)-sensitive neurons were activated by $1 \mathrm{~mm}$ formaldehyde in wild type. Each trace represents the response of a single neuron. Black bars indicate compound application. Caps, Capsaicin. C, TRPA1deficient mice show severe deficits in nociceptive responses to $10 \mu \mathrm{l}$ of $0.2 \%$ formaldehyde injections. Responses represent the time mice spent licking, flicking, or lifting the injected hindpaw $(n>10)$. Error bars indicate \pm SEM. WT, Wild type; K0, knock-out.

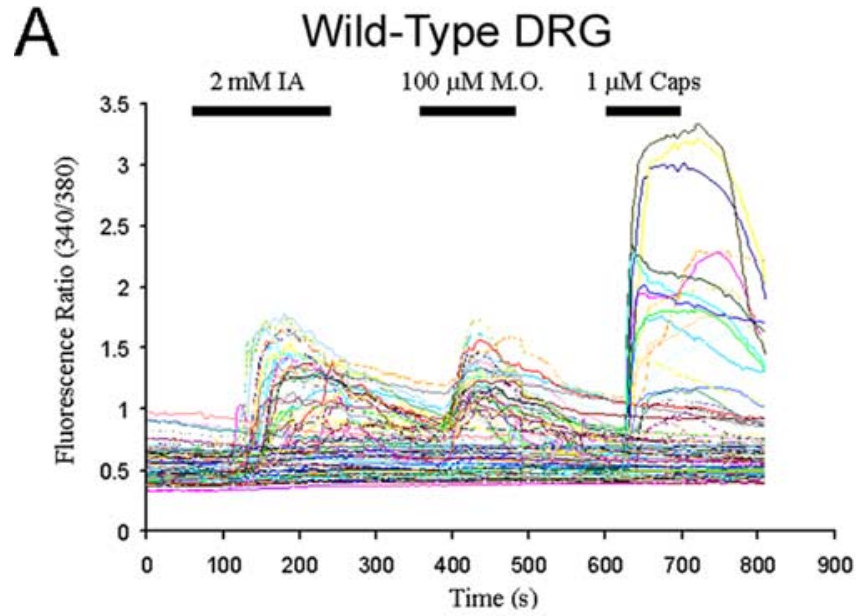

B
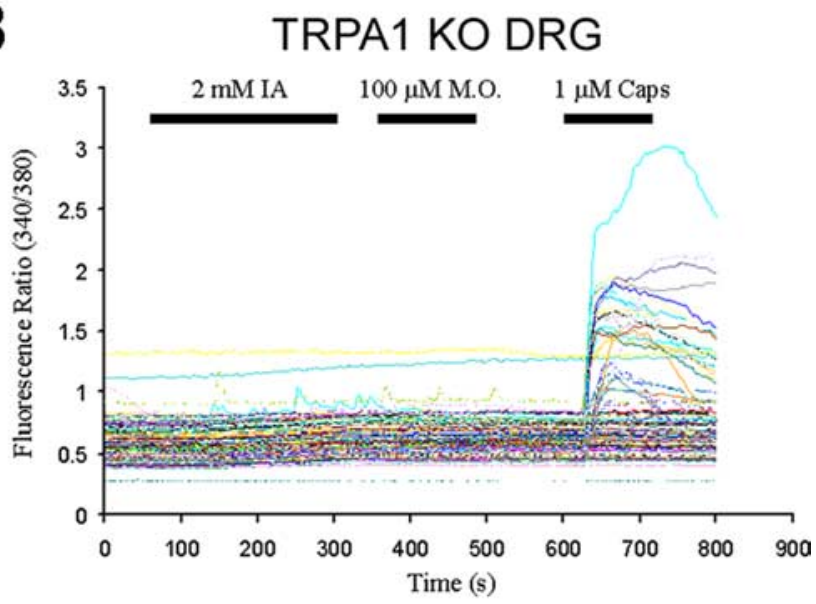

C

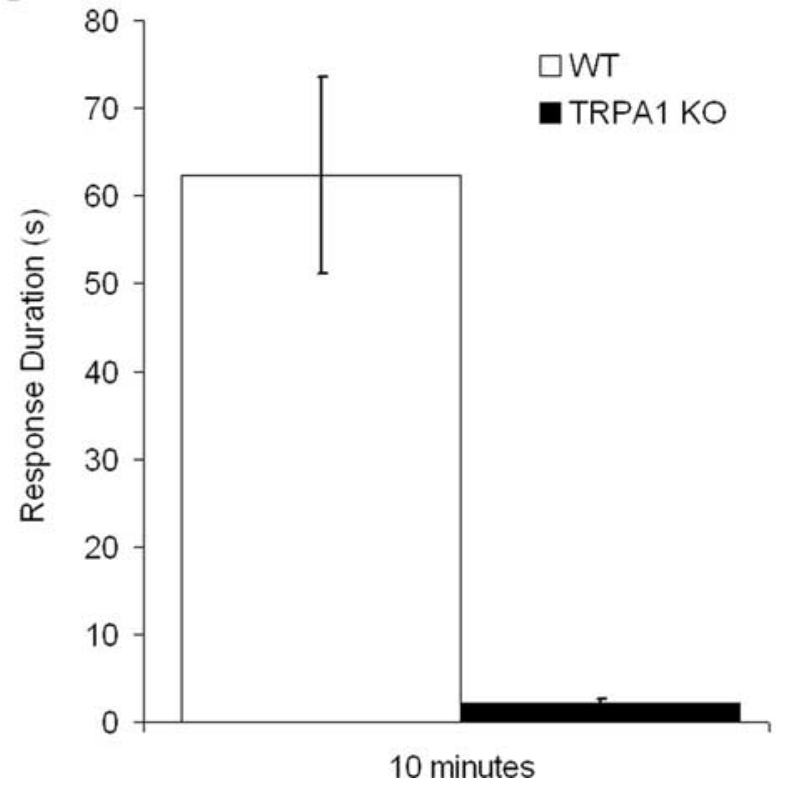

Figure 4. IA elicits pain through TRPA1. $A, B$, IA exclusively activates TRPA 1 in DRG neurons. Ratiometric calcium imaging of cultured adult DRG neurons from wild-type and TRPA1deficient mice is shown. Ninety-six percent of mustard oil (M.0.)-sensitive neurons were activated by $2 \mathrm{~mm} I A$ in wild type. Each trace represents the response of a single neuron. Black bars indicate compound application. Caps, Capsaicin. C, TRPA1-deficient mice show severe deficits in nociceptive responses to a $10 \mu \mathrm{l}$ injection of $15 \mathrm{~mm}$ IA. Responses represent the time mice spent licking, flicking, or lifting the injected hindpaw $(n>10)$. Error bars indicate \pm SEM. WT, Wild type; KO, knock-out. 